DOI: https://doi.org/10.24127/ajpm.v10i2.3657

\title{
KEMAMPUAN REPRESENTASI MATEMATIS SISWA DALAM MEMECAHKAN SOAL BERBASIS HOTS DITINJAU GAYA BERPIKIR SEKUENSIAL DAN ACAK
}

\author{
Pratiwi Novitasari $^{1^{*}}$, Budi Usodo ${ }^{2}$, Laila Fitriana ${ }^{3}$ \\ $1^{*, 2,3}$ Universitas Sebelas Maret, Surakarta, Indonesia \\ * Jl. Ir. Sutami No. 36, 57126, Surakarta, Indonesia \\ E-mail: $\quad$ pratiwinovitasari@student.uns.ac.id ${ }^{1 *}$ \\ budi_usodo@yahoo.com ${ }^{2)}$ \\ lailafitriana_fkip@staff.uns.ac.id ${ }^{3)}$
}

Received 01 April 2021; Received in revised form 12 June 2021; Accepted 29 June 2021

\begin{abstract}
Abstrak
Penelitian ini bertujuan untuk mengetahui kemampuan representasi matematis siswa dengan tipe gaya berpikir sekuensial dan acak dalam memecahkan masalah matematika berbasis HOTS. Jenis penelitian ini adalah penelitian deskriptif kualitatif. Instrumen dalam penelitian ini terdiri atas instrumen utama (peneliti) dan instrumen pendukung (angket, tes dan wawancara). Pengumpulan data dilaksanakan secara daring dikarenakan kondisi pandemi covid-19 yang tidak memungkinkan untuk diambil data secara langsung. Teknik analisis data dalam penelitian ini yaitu reduksi data, penyajian data, dan penarikan kesimpulan. Subjek dalam penelitian ini adalah empat siswa yang memiliki gaya berpikir SK, SA, AK, dan AA. Hasil penelitian menunjukkan bahwa siswa dengan gaya berpikir sekuensial konkret mampu memenuhi indikator kemampuan representasi matematis visual, simbolik, dan verbal. Siswa dengan gaya berpikir sekuensial abstrak mampu memenuhi indikator representasi matematis visual dan verbal. Siswa dengan gaya berpikir acak konkret mampu memenuhi indikator kemampuan representasi matematis visual, simbolik, dan verbal. Siswa dengan gaya berpikir acak abstrak hanya mampu memenuhi indikator kemampuan representasi matematis visual dalam memecahkan masalah matematika berbasis HOTS.
\end{abstract}

Kata kunci: Gaya berpikir; HOTS; kemampuan representasi matematis.

\begin{abstract}
This research aims to determine the mathematical representation ability of students with sequential and random thinking styles in solving HOTS-based mathematical problems. This type of research is a qualitative descriptive study. The instrument that used in this research is the main instrument (researcher) and supporting instrument (questionnaire, test, and interviews). The data collection was carried out by online due to the Covid-19 pandemic conditions which made it impossible to collect the data directly. The data analysis techniques of research are reduction data, presentation data, and drawing conclusions. The subjects of this study were four students with CS, AS, CR, and AR thinking style. The results of research showed that students with a concrete sequential thinking style were able to meet the indicators of visual, symbolic, and verbal mathematical representation abilities. Students with an abstract sequential thinking style are able to meet the indicators of visual and verbal mathematical representations. Students with a concrete random thinking style are able to meet the indicators of visual, symbolic, and verbal mathematical representation abilities. Students with abstract random thinking style are only able to meet the indicators of visual mathematical representation ability in solving HOTS-based mathematical problems.
\end{abstract}

Keywords: HOTS; mathematical representation ability; thinking styles.

This is an open access article under the Creative Commons Attribution 4.0 International License 
DOI: https://doi.org/10.24127/ajpm.v10i2.3657

\section{PENDAHULUAN}

Kemampuan

representasi

matematis sangat erat kaitannya dengan kemampuan siswa dalam memecahkan masalah. Herdiman, dkk (2018) menyatakan bahwa kemampuan representasi matematis dapat meningkatkan kemampuan matematis siswa. Zulfah dan Riyanti (2018) menyatakan bahwa representasi matematika merupakan salah satu kompetensi yang selalu hadir dalam pembelajaran matematika. Berdasarkan beberapa pendapat tersebut, dapat disimpulkan bahwa kemampuan representasi matematis sangat penting dimiliki oleh siswa.

NCTM (Rahmawati, dkk: 2017) menyatakan bahwa kemampuan representasi merupakan salah satu indikator kecakapan yang diujikan dalam PISA. Faktanya, berdasarkan hasil studi PISA tahun 2018 terjadi penurunan dibandingkan tahun 2015, yakni dari skor 386 menjadi 379 . Berdasarkan hasil studi TIMSS tahun 2015, Indonesia berada pada peringkat 44 dari 49 negara dengan rata-rata skor 397 yakni pada kategori rendah. Oktaria, dkk (2016) menyatakan bahwa hal tersebut disebabkan oleh kurangnya kemampuan siswa dalam mengungkapkan gagasan dan ide-ide matematika yang dikarenakan banyaknya siswa yang terkendala dengan kemampuan representasinya. Berdasarkan beberapa fakta tersebut, perlu dilakukan penelitian mengenai penyebab rendahnya kemampuan representasi matematis siswa.

$$
\text { Syafri (2017) menyatakan }
$$

bahwa representasi matematis merupakan kemampuan matematika yang berupa pengungkapan ide matematika, dimana ide matematika tersebut dapat berupa pernyataan, definisi, dan sebagainya. Pendapat tersebut sesuai dengan pendapat Absorin dan Sugiman (2018) yang menyatakan bahwa kemampuan representasi matematis merupakan ungkapan dari ide matematika yang ditampilkan untuk menyelesaikan masalah. Berdasarkan beberapa pendapat tersebut, dapat disimpulkan bahwa kemampuan representasi matematis merupakan cara yang digunakan siswa untuk mengungkapkan pemikirannya terhadap masalah matematika.

Goldin dan Kalput (2015) menyatakan bahwa kemampuan representasi matematis dibagi menjadi dua, yaitu representasi internal dan representasi eksternal. Representasi internal berhubungan dengan proses mental yang tidak dapat diamati secara langsung, sedangkan representasi eksternal merupakan hasil dari representasi internal yang dapat diamati secara langsung.

Yudhanegara (2015) menyatakan indikator yang digunakan untuk menilai kemampuan representasi matematis siswa, yaitu : 1) representasi visual; 2) representasi persamaan atau ekspresi matematis; dan 3) kata-kata atau teks tertulis. Hadiastuti, dkk (2019) menyatakan bahwa indikator kemampuan representasi matematis meliputi: 1) representasi visual yang berupa diagram, tabel dan gambar; 2) persamaan matematis atau ekspresi; dan 3) kata-kata tertulis.

Berdasarkan beberapa pendapat tersebut, indikator kemampuan representasi matematis dalam penelitian ini yaitu: 1) representasi visual, yakni menyajikan data ke dalam bentuk gambar; 2) representasi simbolik, yakni,menuliskan rumus serta melakukan perhitungan; dan 3) representasi verbal, yakni menuliskan langkah penyelesaian dengan kata-kata. 
Pratiwi (2019) menyatakan kemampuan matematis siswa adalah diberikannya soal HOTS. Tajudin dan Chinnappan (2016) menyatakan bahwa terdapat keterkaitan antara pemberian soal HOTS dengan representasi. Keterkaitan tersebut meliputi siswa perlu mengubah masalah ke dalam bentuk representasi, dimana transformasi tersebut mengharuskan siswa untuk mengidentifikasi elemen yang diperlukan (Analisis-HOTS). Siswa dapat membangun representasi visual diikuti oleh representasi simbolik (Mencipta-HOTS). Siswa dapat terlibat dalam kegiatan memeriksa berbagai kemungkinan (Evaluasi-HOTS). Hal tersebut menjadi salah satu alasan pemberian soal HOTS kepada siswa dapat lebih mengasah kemampuan representasi matematis siswa.

Mohammed dan Lebar (2017) menyatakan bahwa karakteristik soal HOTS adalah sebagai berikut: (1) terdapat rangsangan, (2) konteks tidak sering digunakan, (3) dikaitkan dengan kehidupan nyata. Brookhart (Kemendikbud, 2019) mengkategorikan tiga proses kognitif paling atas pada taksonomi bloom sebagai proses berpikir tingkat tinggi, yaitu: (1) analisis, (2) evaluasi, (3) Kreasi.

HOTS erat kaitannya dengan pemecahan masalah, sedangkan pemecahan masalah erat kaitannya dengan kemampuan representasi. Berdasarkan hal tersebut, dapat diperoleh kaitan antara pemeca-han masalah dengan kemampuan representasi matematis siswa. Ketika siswa dihadapkan pada suatu masalah, tidak menutup kemungkinan bahwa terdapat perbedaan antara siswa satu dengan siswa yang lainnya. Perbedaan tersebut dapat dikarenakan cara berpikir siswa yang berbeda. Kholiqowati, dkk (2016) menyatakan bahwa perbedaan cara berpikir dapat mempengaruhi proses representasi internal siswa, dimana representasi internal berhubungan dengan representasi eksternal siswa dalam memecahkan masalah. Kholiqowati, dkk (2016) menyatakan bahwa proses representasi internal siswa dapat dipengaruhi karakteristik cara berpikir, dimana representasi internal berhubungan dengan representasi eksternal siswa. Berdasarkan uraian tersebut, dapat ditarik kesimpulan bahwa cara berpikir siswa mempengaruhi keberhasilan siswa dalam memecahkan masalah matematika, sehingga cara berpikir erat kaitannya dengan kemampuan representasi matematis siswa.

Setiap individu mempunyai cara berpikirnya masing-masing. Lestanti, dkk (2016) menyatakan bahwa gaya berpikir merupakan cara khas yang digunakan seseorang dalam beraktivitas mental. Wardani (2015) menyatakan bahwa gaya berpikir merupakan cara yang digunakan individu untuk menerima dan mengolah informasi. Berdasarkan beberapa pendapat tersebut, dapat disimpulkan bahwa gaya berpikir merupakan cara khas seseorang berpikir yang digunakan untuk menerima dan mengolah suatu informasi.

Berdasarkan uraian tersebut, dapat disimpulkan bahwa gaya berpikir seseorang mempengaruhi kemampuan representasi internalnya. Representasi internal tersebut diwujudkan dalam bentuk representasi eksternal, sehingga hasil dari proses berpikir individu satu dapat diamati oleh individu lain.

Gregorc (De Porter dan Hernacki, 2015) menyimpulkan bahwa terdapat dua dominasi otak yaitu kategori sekuensial dan acak, serta persepsi konkret dan abstrak. Dua dominasi otak tersebut dipadukan sehingga menjadi 
empat kelompok gaya berpikir, yaitu sekuensial konkret (SK), sekuensial abstrak (SA), acak konkret (AK), dan acak abstrak (AA). De Porter dan Hernacki (2015) menyatakan bahwa pemikir SK cenderung lebih mudah mengingat dan memperhatikan dengan mudah, mengatur tugas tahap demi tahap dan berusaha mencapai kesempurnaan pada tiap tahap. Pemikir SA cenderung berpikir dalam konsep, serta memiliki ketelitian yang baik. Pemikir AK cenderung cenderung mempunyai sikap yang suka mencoba dan bereksprerimen, serta mengerjakan sesuatu dengan cara mereka sendiri. Pemikir AA cenderung sangat terpengaruh oleh perasaan, dimana perasaan sangat mempengaruhi bagaimana pemikir AA belajar.

Penelitian ini bertujuan untuk mengetahui kemampuan representasi matematis siswa dengan gaya berpikir SK, SA, AK, dan AA dalam memecahkan masalah matematika berbasis HOTS.

\section{METODE PENELITIAN}

Jenis penelitian ini adalah penelitian deskriptif dengan pendekatan kualitatif yang menghasilkan data deskriptif berupa gambaran tantang kemampuan representasi matematis siswa tipe gaya berpikir sekuensial dan acak dalam memecahkan masalah matematika berbasis HOTS.

Subjek dalam penelitian ini meliputi empat siswa dengan masingmasing gaya berpikir, yaitu satu siswa SK, satu siswa SA, satu siswa AK, dan satu siswa AA yang mempunyai gaya berpikir paling dominan diantara siswa yang lain.

Instrumen pada penelitian ini meliputi instrumen utama dan instrumen pendukung. Peneliti sebagai instrumen utama, dan instrumen pendukung yang meliputi angket gaya berpikir, tes kemampuan representasi matematis, dan pedoman wawancara. Angket gaya berpikir digunakan untuk mengetahui gaya berpikir siswa, tes kemampuan representasi matematis digunakan untuk mengetahui kemampuan representasi matematis siswa, serta pedoman wawancara digunakan untuk menggali lebih dalam informasi yang tidak dapat diamati melalui lembar jawaban tertulis tes kemampuan representasi matematis.

Tahapan penelitian dalam
penelitian ini meliputi tahapan
persiapan, tahap pelaksanaan, tahap analisis data, dan tahap penyusunan laporan penelitian. Tahap persiapan meliputi pengkajian teori kemampuan representasi matematis, pemecahan masalah matematika, soal HOTS, gaya berpikir, dan penyusunan instrumen. Tahap pelaksanaan meliputi pemberian angket, penelusuran subjek, pemberian tes pemecahan masalah, dan wawancara.

Instrumen angket gaya berpikir diberikan kepada siswa melalui google form dan dikerjakan oleh selama 15 menit. Instrumen tes kemampuan representasi diberikan kepada siswa melalui googleform dan dikerjakan oleh siswa selama 2 jam, serta untuk pengumpulan hasil pekerjaan, dikumpulkan dan diupload melalui google form dimana hasil jawaban tersebut hanya dapat diakses oleh peneliti.

Tes kemampuan representasi matematis terdiri dari satu soal yakni $1 \mathrm{a}, 1 \mathrm{~b}$, dan 1c. Soal 1a, 1b, dan 1c berturut-turut untuk mengetahui kemampuan representasi matematis visual, simbolik, dan verbal siswa. Hasil tes kemampuan representasi matematis dianalisis untuk mengetahui kemampuan representasi visual, simbolik, dan verbal siswa. Siswa dikatakan memenuhi indikator 
kemampuan representasi matematis visual jika siswa mampu menyajikan data dalam bentuk gambar dengan benar. Siswa dikatakan memenuhi indikator kemampuan representasi matematis simbolik jika siswa mampu menuliskan rumus dengan benar dan melakukan perhitungan dengan tepat. Siswa dikatakan mampu memenuhi indikator kemampuan representasi matematis verbal jika siswa mampu menuliskan langkah penyelesaian menggunakan kata-kata dengan tepat.

Hasil wawancara digunakan untuk mengetahui lebih dalam mengenai kemampuan representasi matematis siswa tipe gaya berpikir sekuensial dan acak dalam memecahkan masalah matematika berbasis HOTS.

Teknik analisis data dalam penelitian ini meliputi tahap reduksi data, penyajian data, dan penarikan kesimpulan. Data gaya berpikir siswa diperoleh dari hasil analisis angket gaya berpikir siswa. Hasil analisis angket gaya berpikir tersebut digunakan untuk mengelompokkan siswa ke dalam empat gaya berpikir, yaitu gaya berpikir sekuensial konkret, sekuensial abstrak, acak konkret, dan acak abstrak. Angket gaya berpikir terdiri dari 32 pernyataan yang telah divalidasi oleh ahli. Pemilihan subjek dipilih satu siswa untuk masing-masing gaya berpikir yang paling dominan.

Triangulasi yang digunakan dalam penelitian ini adalah triangulasi metode berdasarkan hasil tes kemampuan representtasi matematis dan hasil wawancara untuk ditemukan data yang valid.

\section{HASIL DAN PEMBAHASAN}

Angket gaya berpikir diberikan kepada 32 siswa kelas VIII SMP Negeri 2 Ngawi. Berdasarkan hasil analisis angket gaya berpikir tersebut diperoleh 5 siswa dengan gaya berpikir sekuensial konkret (SK), 8 siswa dengan gaya berpikir sekuensial abstrak (SA), 8 siswa dengan gaya berpikir acak konkret (AK), 4 siswa dengan gaya berpikir acak abstrak, dan 7 siswa dengan gaya berpikir gabungan. Berdasarkan data hasil analisis angket tersebut dipilih empat subjek, yaitu satu siswa pada masing-masing gaya berpikir yang memiliki skor tertinggi (yang paling dominan).

\section{Siswa dengan Gaya Berpikir SK}

Hasil tes tertulis untuk masalah nomor 1a oleh subjek dengan gaya berpikir SK disajikan pada Gambar 1.

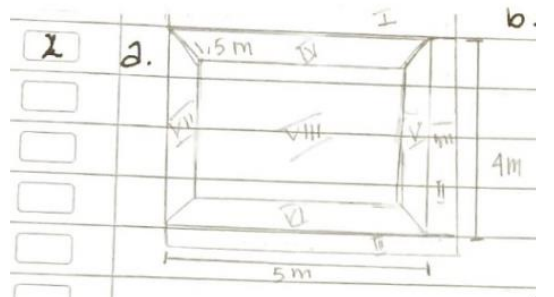

Gambar 1. Jawaban 1a oleh subjek dengan gaya berpikir SK

Gambar 1 merupakan jawaban tertulis oleh subjek dengan gaya berpikir SK untuk soal nomor 1a. Berdasarkan hasil tes tersebut untuk soal 1a, subjek SK mampu membuat ilustrasi dari masalah yang diberikan. Terlihat bahwa subjek SK menggambar ilustrasi kolam terlihat dari atas, serta menuliskan keterangan pada masingmasing bagian kolam dan jalan setapak untuk mempermudah dalam memahami maksud soal.

Rangkuman hasil wawancara dengan subjek SK mengenai soal nomor 1a adalah sebagai berikut : 1) subjek SK tidak mengalami kesulitan ketika menggambar ilustrasi dari masalah yang diberikan; 2) subjek SK menggambar ilustrasi dari kolam menjadi beberapa bagian untuk mempermudah dalam melakukan perhitungan. 
DOI: https://doi.org/10.24127/ajpm.v10i2.3657

Berdasarkan hasil tes dan rangkuman wawancara tersebut, dapat disimpulkan bahwa subjek dengan gaya berpikir SK mampu memenuhi indikator kemampuan representasi matematis visual, yakni mampu menyajikan data dalam bentuk gambar dengan benar. Hal tersebut sesuai dengan penelitian yang dilakukan oleh Utami, dkk (2020) yang menyatakan bahwa siswa dengan gaya berpikir SK mampu membuat ilustrasi yang diberikan dalam bentuk gambar, tabel, grafik, dan diagram. Hasil tes tertulis untuk masalah nomor $1 \mathrm{~b}$ oleh subjek dengan gaya berpikir SK disajikan pada Gambar 2.

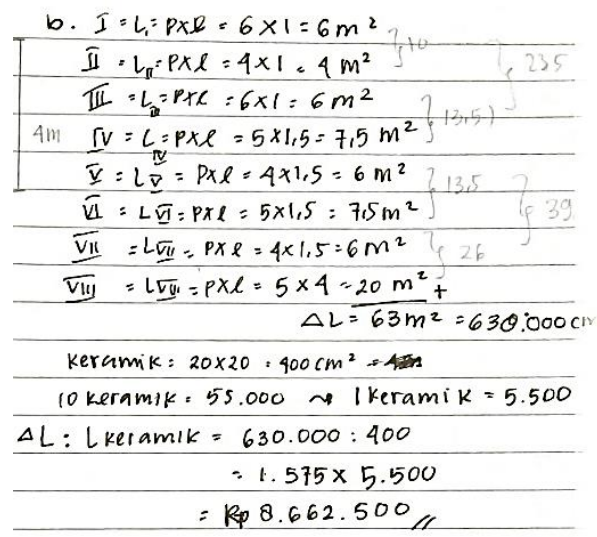

Gambar 2. Jawaban 1b oleh subjek dengan gaya berpikir SK

Gambar 2 merupakan jawaban tertulis oleh subjek SK untuk soal nomor 1b. Terlihat bahwa subjek SK menghitung luas yang dilapisi keramik dengan membagi menjadi beberapa daerah, yaitu daerah I sampai VIII. Masing-masing daerah dihitung dengan tepat, sehingga ditemukan luas daerah yang dilapisi keramik yaitu $63 \mathrm{~m}^{2}$. Setelah ditemukan luas daerah yang dilapisi keramik dalam satuan $\mathrm{m}^{2}$, kemudian diubah menjadi satuan $\mathrm{cm}^{2}$. Subjek SK kemudian mencari harga per keramik dengan membagi harga satu dus keramik dengan isi satu dus

keramik, setelah itu membagi luas daerah yang dilapisi keramik dengan luas satu keramik untuk mencari banyaknya keramik yang dibutuhkan. Langkah terakhir yaitu mengalikan harga satu keramik dengan banyaknya keramik yang dibutuhkan.

Rangkuman hasil wawancara dengan subjek SK mengenai soal nomor $1 \mathrm{~b}$ adalah sebagai berikut: 1) subjek SK tidak mengalami kesulitan ketika melakukan perhitungan; 2) subjek SK mampu menjelaskan langkah perhitungan yang dilakukan.

Berdasarkan hal tes tertulis dan kutipan wawancara tersebut dapat disimpulkan bahwa subjek SK mampu memenuhi indikator kemampuan representasi matematis simbolik, yaitu mampu menuliskan rumus dengan benar dan melakukan perhitungan dengan tepat. Hasil tes tertulis untuk masalah nomor 1c oleh subjek dengan gaya berpikir SK disajikan pada Gambar 3.

c. Pertama kita cari duas masing" bangun datar, kemudran
karena tadi masin 10 keramik agar mudan dijadikan H/Ikeramik
lalu kita cari beraja keramik yang dibutunkan, demudian
dikalikan dengan Harga perkeramik.

Gambar 3. Jawaban 1c oleh subjek dengan gaya berpikir SK

Gambar 3 merupakan jawaban tertulis oleh SK untuk soal nomor 1c. Terlihat bahwa subjek SK mampu menuliskan langkah penyelesaian menggunakan kata-kata dengan tepat. Rangkuman hasil wawancara dengan subjek SK mengenai soal 1c adalah sebagai berikut: 1) subjek SK tidak mengalami kesulitan ketika menuliskan langkah penyelesaian dengan kata-kata tertulis; 2) subjek SK menjelaskan langkah penyelesaian sesuai dengan jawaban tertulis yang diberikan.

Berdasarkan hal tersebut dapat disimpulkan bahwa subjek SK mampu memenuhi indikator kemampuan 
representasi matematis verbal, yaitu mampu menuliskan langkah-langkah penyelesaian menggunakan kata-kata dengan tepat.

Berdasarkan hasil tes tertulis dan rangkuman hasil wawancara dapat disimpulkan bahwa subjek SK mampu memenuhi indikator kemampuan representasi matematis visual, simbolik, dan verbal dalam memecahkan masalah matematika berbasis HOTS. Hal tersebut sesuai dengan penelitian yang dilakukan oleh Kholiqowati, dkk (2016) yang menyatakan bahwa siswa dengan gaya berpikir SK mempunyai kemampuan representasi visual dan simbolik yang sangat baik.

Berdasarkan hasil tes tertulis dan wawancara, dapat disimpulkan bahwa subjek dengan gaya berpikir SK cenderung mengingat rumus dan informasi dengan mudah, serta mengerjakan tugas secara urut dan rapi. Hal tersebut sesuai dengan pernyataan Gregorc (De Porter dan Hernacki, 2015) yang menyatakan bahwa orang dengan gaya berpikir SK cenderung mengingat rumus dan detail dengan mudah, menyusun tugas secara tahap demi tahap dan teratur. Hal tersebut juga sesuai dengan penelitian yang dilakukan oleh Djadir, dkk (2018) yang menyatakan bahwa siswa dengan gaya berpikir SK cenderung menyelesaikan masalah secara tahap demi tahap.

\section{Siswa dengan Gaya Berpikir SA}

Hasil tes tertulis untuk masalah nomor 1a oleh subjek dengan gaya berpikir SA disajikan pada Gambar 4. Pada Gambar 4 ditunjukkan bahwa subjek SA mampu menggambar ilustrasi dari masalah yang diberikan, yakni menggambar kolam beserta jalan setapak pada sekeliling kolam kecuali salah satu sisi kolam dengan benar. a. Gambar llustras.

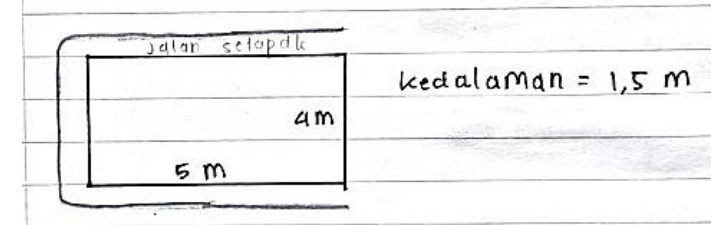

Gambar 4. Jawaban 1a oleh subjek dengan gaya berpikir SA

Rangkuman hasil wawancara dengan subjek SA mengenai soal nomor 1a adalah sebagai berikut: 1) subjek SA tidak mengalami kesulitan ketika menggambar ilustrasi dari masalah; 2) subjek SA menggambar sesuai dengan petunjuk yang diberikan soal.

Berdasarkan jawaban tertulis dan Rangkuman hasil wawancara dapat disimpulkan bahwa subjek SA mampu memenuhi indikator kemampuan representasi visual, yaitu mampu menyajikan data dalam bentuk gambar dengan benar. Hal tersebut sesuai dengan penelitian yang dilakukan oleh Utami, dkk (2020) yang menyatakan bahwa siswa SA mampu membuat ilustrasi dari masalah berupa grafik, tabel, gambar, dan diagram.

Hasil tes tertulis untuk masalah nomor $1 \mathrm{~b}$ oleh subjek dengan gaya berpikir SA disajikan pada Gambar 5.

\footnotetext{
b. Kelling =

. $5 \mathrm{~m} \times 1,5 \mathrm{~m}=7,5 \mathrm{~m}^{2}$

$5 m \times 1,5 m=7,5 \mathrm{~m}^{2}$

$4 m \times 1,5 m=6 m^{2}$

$4 m \times 1,5 \mathrm{~m}=6 \mathrm{~m}^{2}$

$5 \mathrm{~m} \times 4 \mathrm{~m}=\frac{20 \mathrm{~m}^{2}}{47 \mathrm{~m}^{2}}$

keramik =

$20 \times 20 \mathrm{~cm}=400 \mathrm{~cm}^{2}=0,04 \mathrm{~m}^{2} \times 10=0,4 \mathrm{~m}^{2}$

Keramile yang dibutuhlean $=$

$\frac{47 \mathrm{~m}^{2}}{0.9 \mathrm{~m}^{2}}=\frac{117,5}{\text { Jadi, anggar an kurang } 50.000 .}$

Gambar 5. Jawaban 1b oleh subjek dengan gaya berpikir SA

Gambar 5 menunjukkan jawaban tertulis oleh subjek SA untuk soal $1 b$. Jawaban tersebut menunjukkan bahwa
} 
subjek SA tidak mampu melakukan perhitungan dengan tepat. Hal tersebut ditandai dengan subjek SA yang tidak menghitung luas jalan setapak, sehingga menyebabkan perhitungan salah dan anggaran untuk memberli keramik tidak dapat ditemukan dengan benar.

Rangkuman hasil wawancara dengan subjek SA mengenai soal nomor $1 \mathrm{~b}$ adalah sebagai berikut: 1) subjek SA mengalami kesulitan ketika mengerjakan perhitungan; 2) subjek SA mengalami kebingungan memahami maksud soal, sehingga tidak mencantumkan dan tidak menghitung luas jalan setapak.

Berdasarkan jawaban tertulis dan rangkuman hasil wawancara, dapat disimpulkan bahwa subjek SA tidak dapat memenuhi indikator kemampuan representasi matematis simbolik, yaitu menulis rumus dengan tepat dan melakukan perhitungan dengan benar.

Hasil tes tertulis untuk masalah nomor 1c oleh subjek dengan gaya berpikir SA disajikan pada Gambar 6.

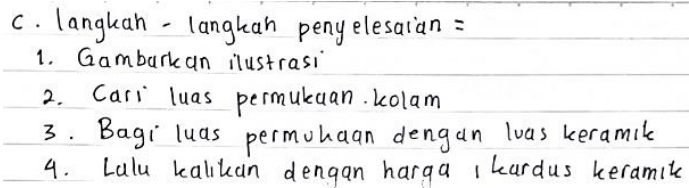

Gambar 6. Jawaban 1c oleh subjek dengan gaya berpikir SA

Gambar 6 merupakan jawaban tertulis oleh subjek SA untuk soal nomor 1c. Jawaban tersebut menunjukkan bahwa subjek SA mampu menuliskan langkah penyelesaian menggunakan kata-kata dengan tepat.

Rangkuman hasil wawancara dengan subjek SA mengenai soal nomor 1c adalah sebagai berikut: 1) subjek SA tidak mengalami kesulitan dalam menuliskan langkah penyelesaian dengan kata-kata; 2) langkah penyelesaian yang dijelaskan sesuai dengan jawaban tertulis. Berdasarkan jawaban tertulis dan rangkuman hasil wawancara, dapat disimpulkan bahwa SA mampu memenuhi indikator kemampuan representasi matematis verbal, yaitu mampu menuliskan langkah-langkah penyelesaian menggunakan kata-kata dengan tepat. Selain itu, subjek SA mampu memenuhi indikator kemampu-an representasi matematis visual dan verbal, namun tidak mampu memenuhi indikator kemampuan representasi matematis simbolik dalam memecahkan masalah matematika berbasis HOTS. Hal tersebut sesuai dengan penelitian yang dilakukan oleh Kholiqowati, dkk (2016) yang menyatakan bahwa siswa dengan gaya berpikir SA mempunyai kemampuan representasi visual sangat baik.

Subjek dengan gaya berpikir SA tersebut mengerjakan tugas dengan urut dan teratur, namun tidak memiliki ketelitian yang baik. Hal tersebut berbeda dengan pernyataan oleh Gregorc (De Porter dan Hernacki, 2015) yang menyatakan bahwa orang dengan gaya berpikir SA cenderung teliti. Berdasarkan hasil wawancara, ketidaktelitian tersebut dikarenakan kondisi yang tidak kondusif ketika subjek SA mengerjakan soal yang diberikan, sehingga subjek SA merasa terganggu dan tidak bisa maksimal dalam mengerjakan masalah yang diberikan.

\section{Subjek dengan Gaya Berpikir AK}

Hasil tes tertulis untuk masalah nomor 1a oleh subjek dengan gaya berpikir AK disajikan pada Gambar 7 .

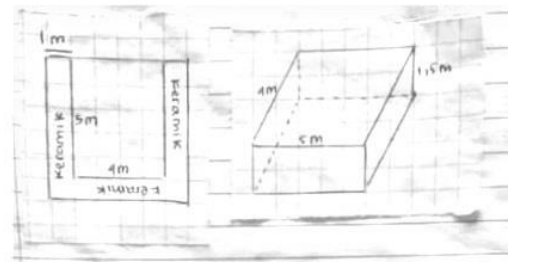

Gambar 7. Jawaban 1a oleh subjek dengan gaya berpikir AK 
DOI: https://doi.org/10.24127/ajpm.v10i2.3657

Jawaban nomor 1a menunjukkan bahwa subjek AK mampu menggambar ilustrasi dari masalah yang diberikan, yakni menggambar kolam dan jalan setapak dengan benar. Terlihat bahwa subjek AK menggambar dua ilustrasi dari masalah yang diberikan, yang pertama menggambar ilustrasi kolam terlihat dari atas dan untuk gambar kedua menggambar ilustrasi kolam terlihat dari samping.

Rangkuman hasil wawancara dengan subjek AK mengenai soal nomor 1a adalah sebagai berikut: 1) subjek AK tidak mengalami kesulitan dalam menggambar ilustrasi dari masalah yang diberikan; 2) langkah dalam menggambar ilustrasi tersebut adalah menggambar ukuran kolam terlebih dahulu, kemudian menggambar jalan setapak di sekeliling kolam, kecuali satu sisinya.

Berdasarkan jawaban tertulis dan rangkuman hasil penelitian, dapat disimpulkan bahwa subjek AK mampu memenuhi indikator kemampuan representasi visual, yaitu mampu menyajikan data dalam bentuk gambar dengan benar. Hasil tes tertulis untuk masalah nomor $1 \mathrm{~b}$ oleh subjek dengan gaya berpikir AK disajikan pada Gambar 8.

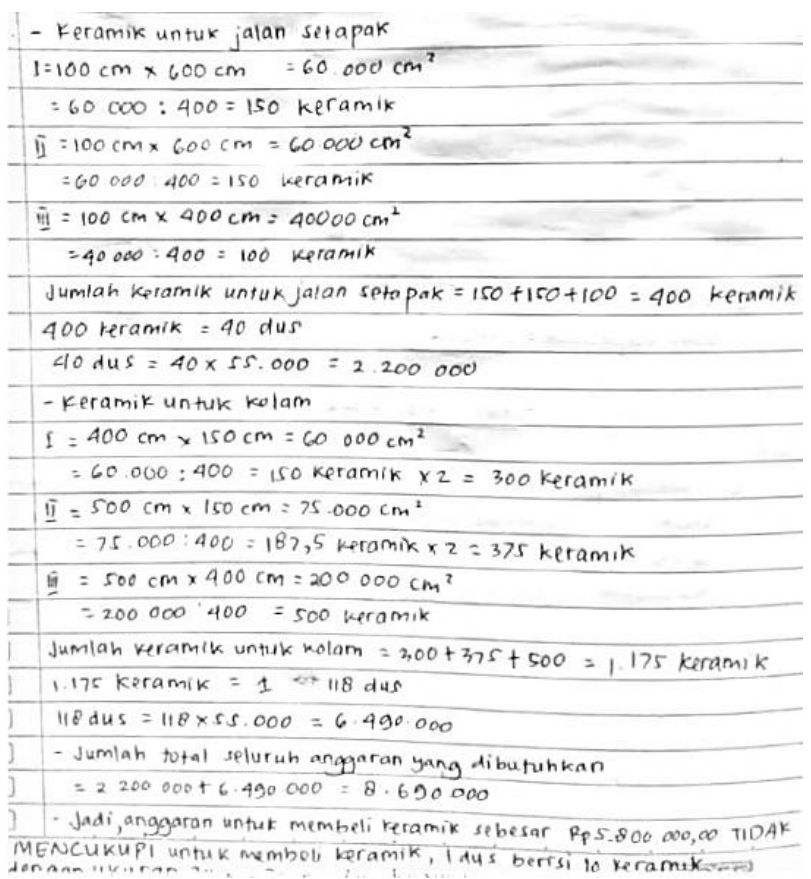

Gambar 8. Jawaban 1b oleh subjek dengan gaya berpikir AK

Gambar 8 merupakan jawaban tertulis oleh subjek AK untuk soal nomor $1 \mathrm{~b}$. Jawaban untuk soal $1 \mathrm{~b}$ menunjukkan bahwa subjek AK menghitung terlebih dahulu masingmasing luas permukaan kolam dan jalan setapak yang akan dilapisi keramik dengan terlebih dahulu mengubah satuan meter menjadi centi meter agar mempermudah melakukan perhitungan.
Setelah luas permukaan kolam dan luas jalan setapak ditemukan, masingmasing luas dibagi dengan luas keramik untuk mencari jumlah keramik yang dibutuhkan dari masing-masing bagian kolam. Setelah itu, AK menjumlah total seluruh keramik yang dibutuhkan dan mengalikan dengan harga keramik perdus hingga ditemukan anggaran yang diperlukan dengan tepat. 
Rangkuman hasil wawancara dengan subjek AK adalah sebagai berikut: 1) subjek AK awalnya mengalami kebingungan untuk menggunakan rumus; 2) subjek AK mencoba menggunakan berbagai cara hingga akhirnya menemukan solusi penyelesaian dengan tepat.

Berdasarkan jawaban tertulis dan rangkuman hasil wawancara menunjukkan bahwa subjek AK mampu memenuhi indikator kemampuan representasi matematis simbolik, yaitu menuliskan rumus dengan benar dan melakukan perhitungan dengan tepat. Hasil tes tertulis untuk masalah nomor 1c oleh subjek dengan gaya berpikir AK dapat dilihat pada Gambar 9.

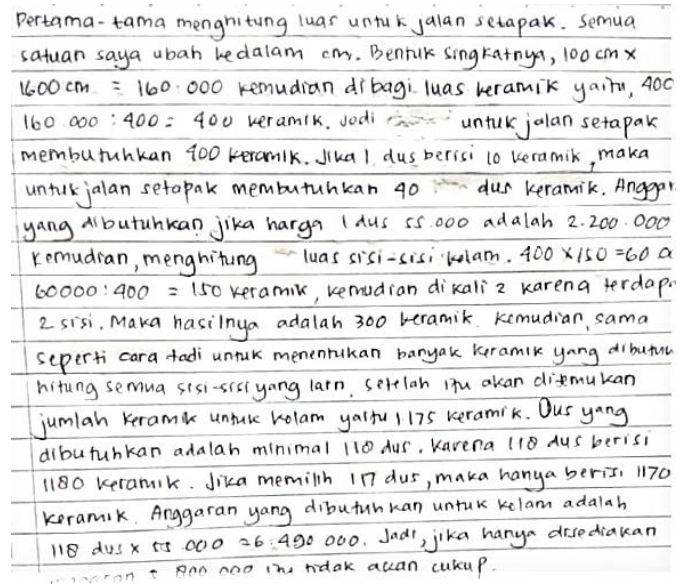

Gambar 9. Jawaban 1c oleh subjek dengan gaya berpikir AK

Gambar 9 merupakan jawaban tertulis oleh subjek AK untuk soal nomor 1c. Jawaban untuk soal 1c menunjukkan bahwa subjek AK mampu menuliskan langkah penyelesaian dengan tepat. Subjek AK mampu merangkai kata sesuai dengan apa yang dikerjakan.

Rangkuman hasil wawancara dengan subjek AK mengenai soal 1c adalah sebagai berikut: 1) subjek AK tidak mengalami kesulitan ketika menuliskan langkah penyelesaian dengan kata-kata; 2) subjek AK mampu menjelaskan langkah penyelesaian sesuai dengan yang dituliskan pada lembar jawaban.

Berdasarkan jawaban tertulis dan rangkuman hasil wawancara, dapat disimpulkan bahwa subjek AK mampu memenuhi indikator kemampuan representasi matematis verbal, yaitu mampu menuliskan langkah-langkah penyelesaian menggunakan kata-kata dengan tepat.

Berdasarkan jawaban tertulis dan rangkuman hasil wawancara dapat disimpulkan bahwa subjek AK mampu memenuhi indikator kemampuan representasi matematis visual, simbolik, dan verbal dalam memecahkan masalah matematika berbasis HOTS. Hal tersebut sesuai dengan penelitian yang dilakukan oleh Kholiqowati, dkk (2016) yang menyatakan bahwa siswa dengan gaya berpikir AK mempunyai kemampuan representasi visual yang baik, serta sesuai dengan penelitian yang dilakukan oleh Hadiastuti, dkk (2019) yang menyatakan bahwa siswa dengan gaya berpikir AK mempunyai kemampuan representasi simbolik yang sangat baik.

Subjek dengan gaya berpikir AK tersebut cenderung suka mencoba dan mengerjakan sesuatu dengan caranya sendiri. Hal tersebut dapat dilihat pada hasil tes tertulis dimana subjek AK menggambar dua gambar berbeda, melakukan perhitungan dengan cara yang berbeda pula. Berdasarkan hasil wawancara, subjek AK mengaku telah mencoba dua cara untuk mengerjakan soal tersebut. Hal tersebut membuktikan bahwa subjek AK suka mencoba sesuatu untuk menyelesaikan tugasnya. Hal tersebut sesuai dengan ciri gaya berpikir AK menurut Gregorc (De Porter dan Hernacki, 2015) yang menyatakan bahwa orang AK 
cenderung suka mencoba hal baru dengan caranya sendiri dan suka mencoba-coba. Hal tersebut sesuai juga dengan penelitian yang dilakukan oleh Djadir, dkk (2018) yang menyatakan bahwa siswa dengan gaya berpikir acak konkret cenderung menggunakan strategi menebak atau uji coba dalam memecahkan masalah matematika.

\section{Subjek dengan Gaya Berpikir AA}

Hasil tes tertulis untuk masalah nomor 1a oleh subjek dengan gaya berpikir AA disajikan pada Gambar 10.

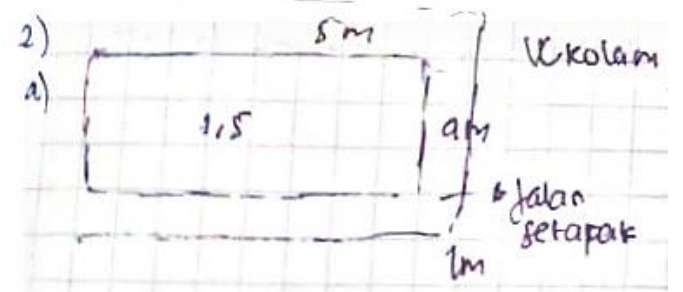

Gambar 10. Jawaban 1a oleh subjek dengan gaya berpikir AA

Jawaban untuk soal 1a yang ditunjukkan pada Gambar 10 menunjukkan bahwa subjek AA mampu menggambar ilustrasi dari masalah yang diberikan dengan benar, meskipun tidak digambar dengan rapi.

Rangkuman hasil wawancara dengan subjek AA mengenai soal nomor 1a adalah sebagai berikut: 1) subjek AA tidak mengalami kesulitan dalam menggambar ilustrasi dari masalah yang diberikan; 2) subjek AA menggambar sesuai dengan apa yang diketahui soal.

Berdasarkan jawaban tertulis dan rangkuman hasil penelitian, dapat disimpulkan bahwa subjek AA mampu memenuhi indikator kemampuan representasi visual, yaitu mampu menyajikan data dalam bentuk gambar.

Hasil tes tertulis untuk masalah nomor $1 \mathrm{~b}$ oleh subjek dengan gaya berpikir AA disajikan pada Gambar 11 .

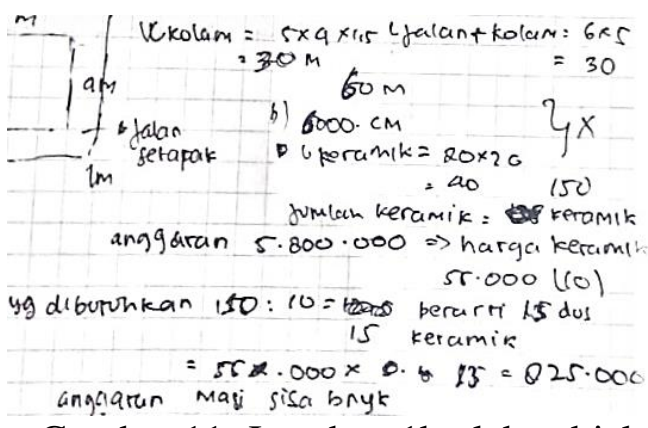

Gambar 11. Jawaban 1b oleh subjek dengan gaya berpikir AA

Gambar 11 merupakan jawaban tertulis oleh subjek AA untuk soal nomor 1b. Jawaban untuk soal nomor 1b menunjukkan bahwa subjek AA tidak mampu memahami maksud soal yang diberikan. Terlihat bahwa subjek AA mencari volume kolam, dimana seharusnya yang dicari adalah luas permukaan kolam dan luas jalan setapak. Hal tersebut menyebabkan perhitungan tidak tepat dan anggaran yang diperlukan untuk melapisi kolam dan jalan setapak tidak dapat ditemukan dengan tepat.

Rangkuman hasil wawancara dengan subjek AA mengenai soal nomor $1 \mathrm{~b}$ adalah sebagai berikut: 1) subjek AA mengalami kesulitan ketika memahami maksud soal; 2) subjek AA kebingungan melakukan perhitungan.

Berdasarkan jawaban tertulis dan rangkuman hasil wawancara, dapat disimpulkan bahwa subjek AA tidak mampu memenuhi indikator kemampuan representasi simbolik, yaitu tidak mampu menuliskan rumus dengan benar dan melakukan perhitungan dengan tepat. Selanjutnya, hasil tes tertulis untuk masalah nomor 1c oleh subjek dengan gaya berpikir AK disajikan pada Gambar 12.

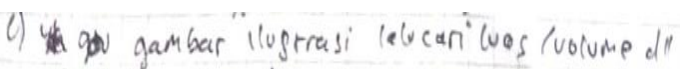
long keramik.d lalv "higgaran.a, , ,

Gambar 12. Jawaban 1c oleh subjek dengan gaya berpikir AA
} 
Jawaban untuk soal nomor 1c yang ditunjukkan pada Gambar 12 menunjukkan bahwa subjek AA tidak dapat menuliskan dengan lengkap langkah penyelesaian menggunakan kata-kata. Subjek AA hanya menggambar ilustrasi, mencari luas dan anggaran, sedangkan urutan pengerjaan tidak dituliskan secara detail. Tulisan subjek AA juga tidak rapi dan tidak urut.

Rangkuman hasil wawancara dengan subjek AA untuk soal nomor 1c adalah sebagai berikut: 1) subjek AA mengalami kesulitan dalam menuliskan langkah penyelesaian menggunakan kata-kata; 2) subjek AA mengalami kebingungan dikarenakan tugas lain yang menumpuk, sehingga tidak dapat mengerjakan secara maksimal.

Berdasarkan jawaban tertulis dan rangkuman hasil wawancara, dapat disimpulkan bahwa subjek AA tidak mampu memenuhi indikator kemampuan representasi verbal, yaitu menuliskan langkah-langkah penyelesaian dengan kata-kata dengan tepat.

Berdasarkan jawaban tertulis dan rangkuman hasil wawancara dapat disimpulkan bahwa subjek AA mampu memenuhi indikator kemampuan representasi matematis visual, namun tidak mampu memenuhi indikator kemampuan representasi matematis simbolik dan verbal dalam memecahkan masalah matematika berbasis HOTS. Hal tersebut sesuai dengan penelitian yang dilakukan oleh Kholiqowati, dkk (2016) yang menyatakan bahwa siswa dengan gaya berpikir AA mempunyai kemampuan representasi visual yang baik, namun kemampuan representasi verbal kurang sekali.

Subjek dengan gaya berpikir AA tersebut cenderung mengerjakan soal dengan tidak runtut dan tidak rapi. Berdasarkan hasil wawancara dapat diketahui bahwa ketika mengerjakan tes, subjek AA memikirkan tugas lain yang juga belum selesai serta kondisi yang tidak mendukung. Hal tersebut sesuai dengan penyataan Gregorc ( De Porter dan Hernacki, 2015) yang menyatakan bahwa orang dengan gaya berpikir AA cenderung dipengaruhi oleh perasaan, sehingga perasaan mempengaruhi bagaimana mereka belajar.

\section{KESIMPULAN DAN SARAN}

Berdasarkan hasil analisis data penelitian, diperoleh kesimpulan tentang kemampuan representasi matematis siswa dalam memecahkan soal berbasis HOTS ditinjau dari gaya berpikir sekuensial dan acak. Siswa dengan gaya berpikir sekuensial konkret mampu memenuhi indikator kemampuan representasi matematis visual, yaitu mampu menyajikan data dalam bentuk gambar dengan benar. Mampu memenuhi indikator kemampuan representasi matematis simbolik, yaitu menuliskan rumus dengan tepat dan melakukan perhitungan dengan benar, serta siswa mampu memenuhi indikator kemampuan representasi verbal, yaitu mampu menuliskan langkah penyelesaian dengan kata-kata.

Siswa dengan gaya berpikir sekuensial abstrak mampu memenuhi indikator representasi matematis visual dan representasi verbal. Siswa dengan gaya berpikir acak konkret mampu memenuhi indikator kemampuan representasi matematis visual, representasi matematis simbolik, dan representasi verbal. Terakhir untuk siswa dengan gaya berpikir acak abstrak hanya mampu memenuhi indikator kemampuan representasi matematis visual.

Berdasarkan hasil penelitian dan kesimpulan, maka saran yang diberikan oleh adalah sebagai berikut. Perbedaan 
gaya berpikir mempengaruhi bagaimana siswa memikirkan solusi atau langkah penyelesaian dari masalah matematika yang dihadapi, sehingga berpengaruh pada hasil belajar siswa. Berdasarkan hal tersebut, siswa diharapkan dapat menyeimbangkan gaya berpikirnya masing-masing agar siswa dapat mengendalikan cara beraksi dalam segala macam situasi dan dapat memecahkan masalah dengan memilih solusi yang paling efektif.

Guru diharapkan dapat menerapkan metode dan model pembelajaran yang tepat agar dapat memfasilitasi semua siswa dari berbagai macam gaya berpikir.

Penelitian ini terbatas pada siswa yang mempunyai gaya berpikir yang paling dominan, sedangkan terdapat siswa yang mempunyai gaya berpikir gabungan satu atau lebih gaya berpikir lain, sehingga penelitian ini dapat ditindaklanjuti.

\section{DAFTAR PUSTAKA}

Absorin., \& Sugiman. (2018). Eksplorasi Kemampuan Penalaran dan Representasi Matematis Siswa Sekolah Menengah Pertama. Pythagoras: Jurnal Pendidikan Matematika, 13(2), 189-202.

De Porter, B., \& Hernacki, M. (2015). Quantum Learning: Membiasakan Belajar Nyaman dan Menyenangkan. Terj. Alwiyah Abdurrahman. Bandung: Penerbit Kaifa

Djadir., Upu, H., \& Sulfianti, A. (2018). The Profile of Students, Mathematical Problem Solving on the Topic of Two-Variable Linear Equation Systems Based on Thinking Styles. Journal of Physics: Conf. Series 1028.
Goldin, G. A., \& Kalput, J.J. (2015). A Joint Perspective on The Idea of Representation in Learning and Doing Mathematics. Rutgers: The State University of New Jersey.

Hadiastuti, D. I., Soedjoko, E.,\& Mulyono. (2019). Analysis of Mathematical Representation Ability based on Students Thinking Style in Solving OpenEnded Problems. Unnes Journal of Mathematics Education, 8(3), 195-201.

Herdiman, I., Jayanti, K., Pertiwi., K.A.,\& Naila, R. N. (2018). Kemampuan Representasi Matematis Siswa SMP pada Materi Kekongruenan dan Kesebangunan. Jurnal Elemen, 4(2), 216-229.

Kemendikbud. (2019). Panduan Penulisan Soal HOTS. Jakarta: Pusat Penilaian Pendidikan.

Kholiqowati, H., Sugiarto., \& Hidayah, I.(2017). Analisis Kemampuan Representasi Matematis Ditinjau dari Karakteristik Cara Berpikir Siswa dalam Pembelajaran dengan Pendekatan Saintifik. Unnes Journal of Mathematics Education, 5(3), 234-242.

Lestanti, M. M., Isnarto., \& Supriyono. (2016). Analisis Kemampuan Pemecahan Masalah Ditinjau dari Karakteristik Xara Berpikir Siswa dalam Model Problem Based Learning. Unnes Journal of Mathematics Education, 5(1), 1723.

Mohammed, R., \& Lebar, O. (2017). Authentic Assessment in Assessing Higher Order Thinking Skills. International Journal of Academic Research in Business and Social Science, 7(2), 466-476. 
Oktaria, M., Alam, A. K., \& Sulistiawati. (2016). Penggunaan Media Software GeoGebra untuk Meningkatkan Kemampuan Representasi Matematis Siswa SMP Kelas VIII. Jurnal Matematika Kreatif-Inovatif, 7(1), 99-107.

Pratiwi, I. (2019). Efek Program PISA terhadap Kurikulum di Indonesia. Jurnal Pendidikan dan Kebudayaan, 4(1), 51-71.

Rahmawati, D., Purwanto., Subanji., Hidayanto, E., \& Anwar, R.B. (2017). Process of Mathematical Representation Translation from Verbal into Graphic. International Electronic Journal Of Mathematics Education, 12(3), 367-381.

Syafri, F. S. (2017). Kemampuan Representasi Matematis dan Kemampuan Pembuktian Matematika. Jurnal Edumath, 3(1), 49-55.

Tajudin, N. M., \& Chinnappan, M. (2016). The Link between High Order Thinking Skills, Representation and Concepts in Enhaching TIMSS Tasks. International Journal of Instruction, 9(2), 199-214.

Utami, L. F., Pramudya, I., \& Slamet, I. (2020). Students' Mathematical Communication Skills in Terms of Concrete and Abstract Sequential Thinking Styles. AlJabar: Jurnal Pendidikan Matematika, 11(2), 371-381.

Wardani, E.P. (2015). Analisis Miskonsepsi Siswa pada Materi Pokok Lingkaran Ditinjau dari Kesiapan Belajar dan Gaya Berpikir Siswa Kelas XI IPA SMAN 3 Surakarta Tahun Ajaran 2013/2014. Universitas Sebelas
Maret. Surakarta: Universitas Sebelas Maret.

Yudhanegara, M. R. (2015). Meningkatkan Kemampuan Representasi Matematis Beragam Matematis Siswa Melalui Pembelajaran Berbasis Masalah Terbuka (Penelitian Kuasi Eksperimen Terhadap Siswa Kelas VII SMPN 1 Pagaden, SUbang). Ilmiah Solusi, 1(4), 94103.

Zulfah., \& Rianti, W. (2018). Kemampuan Representasi Matematis Peserta Didik Bangkinang dalam Menyelesaikan Soal PISA 2015. Jurnal Cendekia: Jurnal Pendidikan Matematika, 2(2), 118-127. 